\title{
Ethnoreligious Conflict and Populism: Emotive Political Response in the Rohingya Conflict
}

\section{Costas Laoutides}

\section{check for} updates

Citation: Laoutides, Costas. 2021. Ethnoreligious Conflict and Populism: Emotive Political Response in the Rohingya Conflict. Religions 12: 816. https://doi.org/10.3390/rel12100816

Academic Editor: Daniel H. Levine

Received: 12 August 2021

Accepted: 27 September 2021

Published: 28 September 2021

Publisher's Note: MDPI stays neutral with regard to jurisdictional claims in published maps and institutional affiliations.

Copyright: (c) 2021 by the author Licensee MDPI, Basel, Switzerland This article is an open access article distributed under the terms and conditions of the Creative Commons Attribution (CC BY) license (https:// creativecommons.org/licenses/by/ $4.0 /)$.
School of Humanities and Social Sciences, Faculty of Arts and Education, Melbourne Burwood Campus, Deakin University, Melbourne 3125, Australia; costas.laoutides@deakin.edu.au

\begin{abstract}
The rise of populism in the twenty-first century has been marked by the use of religion and national identity as emotive mobilizing forces to increase in-group solidarity and demarcate the notional boundaries of communities. The process often leads to the exclusion of vulnerable ethnoreligious minorities and to increased violence against them. This article analyses the role of fear as a principal emotion in the context of ethnoreligious conflict with reference to the Rohingya conflict in Myanmar. The article is divided in three parts. Part one explores notions of collective fear with reference to religious and ethnic conflict. Part two illustrates how collective existential fear has fuelled populist religious infused responses to the Rohignya conflict leading to the latest mass exodus of 2017. The final part considers whether fear can be an instrument of construction rather than destruction, to help build bridges than destroy, to connect people than isolate them.
\end{abstract}

Keywords: emotions; fear; Rohingya; ethnic conflict; populism; religious conflict; Rakhine

\section{Introduction}

The main aim of this article is to unpack the role of fear as a principal emotion in the context of ethnoreligious conflict with reference to the Rohingya conflict in Myanmar. In doing so the article addresses one of the gaps in the literature on the relation between religion, populism and emotions as identified by Yilmaz and Morieson (2021a). In particular, this article is concerned with identinarian populism, which describes processes of religious classification of populations in diverse societies. Such classifications rely on civilizational dichotomies yet they maintain a secular political program (Yilmaz and Morieson 2021b). One key aspect of ethnoreligious conflicts is the perceived or real threat of a group by another group that generates collective fear and subsequently can lead to collective violence. A key observation from personal anecdotal evidence in Myanmar is that the relationship (or lack thereof) between Buddhists and Rohingya Muslims could be described as an Anderson-in-reverse phenomenon (Anderson 2006). ${ }^{1}$ Imagined community is a term coined by Benedict Anderson to analyse the process of national identity-making in the modern era. Accordingly, nations are socially constructed communities imagined by the people who perceive themselves as members of these groups. Crucially in this context, the imaginary dimension is constitutive and not a mere reflection of collective practices, stories, and symbols. Through the collective agency of the social imaginary, a society is given coherence and identity (Castoriadis 1987). Often, part of the social imaginary of a group is the image of external collectivities and their relationship to them. In exchanges with members of ethnic groups in Myanmar, especially the triangle of ethnic relations between Bamar (or Burmese), Rakhine, and Rohingya, each of the discussants offered, frequently though not always, a very negative depiction of the other side. Sometimes interlocutors were asked to comment on how many people they knew, or have seen, or they have interacted with from the "other side"; often the answer referred to minimal or not at all interaction. Although they had little personal experience of the other group, their opinion and, importantly, their feelings, including existential fear, were very strong and real to them. Imagined enemies, therefore, can be a useful concept to describe identity-making through a process of ongoing 
barbarization of a group they (have learnt to) fear yet they may have not personally come across. The question that follows from this anecdotal observation is why collective fear is endemic in ethnic conflict, how it is formed, and whether it can only be destructive. The article is divided in three parts. Part one explores notions of collective fear with reference to religious and ethnic conflict. Part two draws on secondary sources to illustrate how collective existential fear has fuelled populist religious infused responses to the Rohignya conflict leading to the latest mass exodus of 2017. The final part considers whether fear can be an instrument of construction rather than destruction, to help build bridges than destroy, to connect people than isolate them.

\section{Collective Fear in Ethnoreligious Conflicts}

A starting point for considering the correlation between organized societies and collective fear is Darwin's description of fear that places emphasis on its paralysing and devastating qualities. Darwin (1965, pp. 289-307) presented a descriptive account of the physiological manifestation of fear in facial and body expressions arguing that fear is a reaction to unexpected and perilous events that cause shock and alarm. Accordingly, he viewed fear as an incapacitating emotion precipitated by danger that results in flight. However, Darwin's treatment of fear as a reaction to danger has attracted criticism because it does not address the necessary distinction between the target (cause) and the focus (object) of fear (Schmid 2009; Helm 2001). The target (cause) of fear refers to the conditions under which fear is elicited and which need to be interpreted within the structural nexus and the situational setting in which fear is experienced. The focus (object) of fear relates that which the emotional person is concerned about. For example, certain industries or professionals may fear certain government policies, but the focus of their fear is the viability of the sector and thus of their employment. Such a distinction echoes Ben-Ze'ev (2000, pp. 31-32) and his typology which includes 'emotional cause', 'emotional object', and 'emotional concern' with the latter understood as the emotional appraisal of the situation.

The structural conditions that make an individual or a group experience fear has been depicted in modern political thought by Thomas Hobbes (2004) and his metaphor of the state of nature as the starting point of political organization. Hobbes stresses the role of fear in the anarchical state of nature which prompts the agreement to form the sovereign state-however, once in such a state, individuals still fear the possibility of returning to the state of nature; so, fear provides the emotional basis of statehood. In the structural conditions of anarchy fear dominates because the ability of people to kill each other makes even the strongest feel threatened (Hobbes 2004; Coli 2006; Foucault 2003). Thus, at a basic level fear is experienced in the presence of a threat or danger along with a perceived lack of coping capabilities or skills to deal with the source of fear (Halperin 2016).

In the literature of ethnic conflicts collective fear has been seen as a fundamental factor for escalation to violence (Lake and Rothchild 1998). All sides in a conflict gradually come to fear that the existence of their group is in danger. Such fears can also be exaggerated by an in-group out-group psychology. Fear is likely to prompt the attribution of hostile intentions to others in order to justify and explain one's own apprehensions (Horowitz 1985, p. 180). It is usually associated with an assessment of weakness and lack of control over the situation (Roseman 1984). As such, it is conducive to exaggerating the hostility of others and leads to pessimistic estimates about potential outcomes (Lerner and Keltner 2001). Accordingly, and given the caution and risk aversion generated by fear, people avoid taking any compromise that would increase further the risks. Thus, in an environment of threat and fear there is a potential increase in intolerance, enthocentrism and conservatism (Stephan et al. 2008).

The source of such fear can be the group's narrative depicting the group as being under threat and victimized. In these cases, the more historical narratives emphasize the group's past victimization, the more credible is the arousal of fear which can lead to hate and calls for vengeance (Van Evera 1994). This process is also informed by anxiety-laden perceptions evidenced in the systematic exaggeration of events that forms the subject of 
rumours, particularly regarding the capabilities of opposing groups (Horowitz 2001, p. 87). In this context religion can be instrumentally employed to promote populist agendas. Religious populists provoke religious rage and mobilize the public, which can target religious minorities (Yilmaz and Morieson 2021a). A recent example was the implication of Facebook as the space where a covert operation, by the Myanmar military, was carried out targeting Rohingya Muslims (Mozur 2018). The Rohingya were depicted as invaders who would dominate numerically Northern Rakhine state in Myanmar thus posing an existential threat to the local ethnic Rakhine and to Myanmar at large.

Demographic threats may also increase ethnoreligious fears especially when there is uneven population growth which indicates a potential change of the demographic map in the future. The effect of such a situation is that groups may perceive themselves as potential minorities at the brink of extinction. This is often coupled with ethnic histories that are filled with episodes of peace and war; such histories are always subject to myths and interpretations rather than thorough scrutiny of the actual past events. Once ethnic fears become prevalent among the members of any ethnic group, they justify the use of violence as an act of self-defence. Such fears are necessary conditions for ethnic war because people in fear are more concerned to avoid loss than to pursue gains, so they are mobilized when they are confronted by some threat (Kaufman 2001, pp. 30-34).

Structural changes such as the weakening of the political centre or regime transition leads to a situation characterized as anarchy or emerging anarchy. Under these conditions, fear heightens the desire for security. The target of ethnic violence will be the group that is (perceived as) the biggest threat (Petersen 2002). Ethnic violence results from changes in both desires and beliefs. Individuals decide to resort to ethnic violence, and they need to believe that this is a necessary and feasible strategy. There are multiple versions of the fear narrative with varying foci on belief versus emotion. Fear accounts associated with anarchical conditions are found in versions/adaptations of the security dilemma derived from International Relations (Jervis 1978; Posen 1993; Waltz 1979). However, in these accounts, fear is shared between the mass and the political elites as a response to the evolving conditions of anarchy due to structural changes outside their control. Fear may also be manipulated and heightened to the benefit of some or all elite factions for their own ends (Petersen 2002).

The most popular version of these approaches is Barry Posen's ethnic security dilemma thesis (Posen 1993). Posen argues that periods of collapse and/or transition should be characterised as "emerging anarchy" which increases uncertainty among ethnic groups and the perception of their limited capabilities to deal with it. In such an uncertain environment, two conditions are present. The first is a heightened level of group awareness and solidarity, which offers a ready ability for offensive or defensive mobilization. Solidarity is often invested with negative historical narratives that appeal to the ethnic audience and can expedite the mobilization process. Ethnic groups, uncertain about each other's intentions, will use history as a means to assess the other side in a quickly shifting environment; often the worst examples of past inter-ethnic relations are employed. The second condition, Posen suggests, is social and geographical isolation, which increases the potential for ethnonationalist extremism. Groups more segregated from one another become more vulnerable to rumour and fear. Isolation leads groups to take measures to protect themselves, which may be seen as threatening by other groups especially in the presence of violent interethnic history. Such conditions create a security dilemma escalation (de Figueiredo and Weingast 1999; Lake and Rothchild 1996, 2001; Fearon 1998; Roe 2005).

There are two main observations from the discussion so far about the presence of fear in ethnic conflict. Firstly, fear is generated by structural changes at the societal and intersocietal level developed outside the direct agency of the groups and their elites. However, elites may manipulate fear to safeguard their position as long as there is a background structural shift that can offer the conditions of uncertainty (emerging anarchy). In a nutshell, fear and uncertainty are generated by potential change, a forward-looking process, which cannot be controlled. Second, the overall sense of fear is based on the premise that an actual 
threat does exist which follows from the empirical observation that ethnic groups have the mutual ability to cause harm to each other (Petersen 2002). Such an argument agrees with the proposal by Adam Smith (1982, p. 30) that fear represents what we may possibly suffer. In tune with this line of thinking Ortony et al. (1988, pp. 109-14) suggest that fear is a prospect-based emotion of anticipated danger, it is a displeasure about the prospect of an undesired event (Oatley and Jenkins 1996, p. 260). Thus, change is a potential source of fear, especially when the social experience of the ethnic groups undergoes a structural transition which arouses conflicting perceptions, touching upon existential dimensions, and usually coupled with narratives of radical disagreement. Not all change leads to fear but under the ethnic groups' perceptions of insufficient power to control or adjust to the structural transitions, the anticipated change is likely to lead to fear. The object of fear then, the perceived threat, is not an agent but rather a potential negative outcome of the structural changes. Harm and injury are the direct potential outcomes of the change, and agency (the ethnic group) is implicated because of its possible involvement in the action that may cause harm.

In this context, religion is instrumental in sacralising 'the people' by confining them to an existing religious tradition. This is what Yilmaz and Morieson (2021b) term as "identinarian populism" which classifies peoples on the basis of religion without, however, promoting a political program based on religious teachings per se. Thus it is often secular and aligned with civilizations. Accordingly, religion is employed in framing an 'us vs. them' mentality where in-group religion is portrayed in a positive manner while the religion of the out-group is demonised (Yilmaz and Morieson 2021a).

Fear is an emotional apprehension of a negative prospect in ethnoreligious conflicts and grounded in people's reality (Bar-Tal and Halperin 2013). It is also the dominant emotional implication of intractable conflicts-protracted conflicts with violent episodes where all sides experience an existential threat and believe that the differences at stake are irreconcilable (Elman et al. 2019). When violent conflict is ongoing for many years and the people perceive to be under threat at an existential level then, they have good grounds to feel fear. In fact, after years of exposure to such conditions it may be seen as abnormal not to feel fear (Halperin 2016). The everyday experience of ethnic groups in conflict is characterised by exposure to messages of enmity by the adversaries or to warnings of collective elimination by their leaders. Often such messages are coupled with violence aiming at destroying the other side, such process increase the existential threat and can lead to the development of collective victimhood and siege mentality (Bar-Tal et al. 2009; Halperin et al. 2013).

As pointed above, in the context of ethnic conflicts collective fear is aroused by reference to historical narratives of adversarial inter-ethnic relations. Such narratives are often invested with depiction of the adversaries as inferior, barbarous, and uncivilized. Indeed, the deployment of fear-inducing discourses is a wider phenomenon in contemporary politics that exceeds the boundaries of ethnic conflicts. Mainstream political parties and movements attempt to promote their policies as positive by generating fear (among other emotions) as they form friend-enemy distinctions (Heaney 2013, p. 245). This observation is in tune with Daniel Kahneman's suggestion that "emotional learning may take place through conditioning ... Learned fears can be more easily acquired, fear can be learned by words than by experience" (Kahneman 2011, pp. 237-38). Accordingly, a process of collective identity building can include discourses of otherization for anyone who is unlike the members of the referent group (Said 1991; Bauman 1991; Taylor 2009). In the next section, I explore the progressive learning of fear through religious narrative construction in the conflict of North Rakhine in Myanmar-the locus of a tripartite conflict that resulted in the 2017 exodus of nearly 800,000 Rohingya Muslims.

\section{Learn to Fear in Rakhine State}

Myanmar since its independence in 1948 has faced a series of violent ethnic conflicts some of which continue to the present day (South 2008). Probably the most perplexed 
and challenging of the current conflicts takes place in Rakhine state and it involves the Rohingya Muslims, the Arakanese Buddhists, and the Burmese-controlled Myanmar government. The impact of physical and social destruction has far-reaching consequences that affect the country's democratic transition and international status. After a long period without tensions, the recent episodes of violence started with a communal eruption in 2012 coinciding with the start of the democratic transition in the country. These attacks were targeting Muslims (most of the Muslims in Rakhine state are Rohingya) resulting in two hundred deaths and the displacement of 140,000 people into camps. This episode was followed by a series of other violent incidences, which were signalling the deterioration of the situation and ultimately led to the violence of August-September 2017 when security forces reacting to an attack against a military station forced to the massive flee of Rohingya into neighbour Bangladesh. More than $60 \%$ of the Rohingya population fled the country creating the biggest refugee camp in the world (Médecins Sans Frontières 2017).

The conflict in Rakhine state is about recognition and equality of the Rohignya within the body politic, which is informed by the politics of ethnicity and religion in Myanmar (Ware and Laoutides 2018). At least since 1962 after General Ne Win's coup, Myanmar has framed ethnicity as central to defining the political community at the heart of the state. The idea of minorities conceived primarily along ethnic, racial, and religious lines was imported by the British but while political identities became reified around ethnicity during the 19th century, it was Ne Win who took the previously politically insignificant concept of 'national races' and transformed it into the defining criterion for political membership in Myanmar (Cheesman 2017). Accordingly, the Myanmar constitution privileges 'national races' which are defined as the populations who settled in the country before 1823 (that is prior to the arrival of the British). The concept in this context is synonymous to autochthony and has become institutionalised in the ethnic politics of the country, a mosaic of various degrees of individual recognition and collective autonomy, as it draws borders of inclusion and exclusion with the Rohingya to be the ultimate outcast. For the Arakanese, this conflict is thus a struggle to gain sufficient political power to ensure their cultural survival, and a fair distribution of services and resources. For the Rohingya, it is a struggle for collective membership in the political community-thus for their physical as much as cultural/religious and socio-economic survival.

The situation in Rakhine falls within the definition of an 'intractable conflict' —a longterm unresolvable conflict with violent episodes in which all adversaries experience a threat that generates fear about their collective existence (Elman et al. 2019; Bar-Tal 2013). A key aspect of intractability is its manifestation as a clash of historical narratives, which perceive the conflict as irreconcilable because its key elements are non-negotiable. This is particularly the case around the narratives of origin, the stories that shape and define group identities. Historical accounts, oral or written, are always present in every nation and ethnic group. As constructions of social imaginaries, group narratives are constantly reinvented to shape group identity and increase in-group solidarity, inform intergroup relations, and give understanding to contemporary social realities. Nations and ethnicities use such narratives to propagate and justify images of themselves and 'the Other', and to build cultural identities (Malesevic 2004, pp. 61-76). In intractable contexts, historical narratives heighten the incoming threat from the 'other side', inducing thus further fear for future harm. Simultaneously these narratives build upon a past collective trauma that intensifies the sense of victimhood, increases existential threat, and appears as a righteous justification of their grievances against an immoral and barbarous 'Other'.

As in every intractable conflict, history in Rakhine is questioned by all sides and this contestation is characterised by limited critical analysis of early historical sources and records. The undisputed persecution and the suffering of the Rohingya has created an international audience that inclines to accept Rohingya portrayals of their historical narrative as accurate, despite the fact it often relies on insufficient historical evidence (Leider 2013). The central tenet of the Rohingya narrative is the claim that they are an autochthonous 'national race' with their presence in the land dating back centuries. By 
collapsing the presence of Muslims in the former kingdom of Arakan (today's Rakhine state) from the 14th century until the Burmese invasion in 1784, with the mass importation of India labour dating during the colonial period, the Rohingya narrative promotes a claim of direct line of ancestry that legitimizes their presence in the land (Ware and Laoutides 2018, pp. 78-90). Expanding on this point the narrative depicts the Burmese as the colonizers who during independence from the British in 1948 incorporated in the Burmese state ethnic borderlands where they were historically outsiders; as a senior Rohingya activists captures it: "Don't forget that this is not a country only Burmese. They [the Burmese] forget about that. They think the entire country belongs to them. They have come to occupy and are colonizing our states. Now everyone is required to speak Burmese to be citizens. "Back in the day, there were no Burmese in Arakan to speak their language. They have forgotten that they are outsiders in Rakhine state" (Holt 2019, p. 103, emphasis added). The activist has also a comment for the Arakanese Buddhist leaders: "Almost all of the Rakhine Buddhist politicians are super racist. Before there was a kind of equality between the Rakhine [Arakanese] and Rohingya, but now the Arakanese want to expel the Rohingya. There were always some anti-Rohingya, but now it has become normative across the board. Ethnic cleansing is occurring" (Holt 2019, p. 104). The current existential fear is anchored in a history of victimhood that dwells on the massacres and ethnic cleansing between Rohingya and Arakanese during the Second World War. Both sides suffered greatly during these episodes, yet each side portrayed themselves as the victim and in essence this violence created the basis for mutual fear and future divisions between the two communities in Rakhine (Leider 2013). In the effort to prove autochthony and qualify as a 'national race', the Rohingya narrative promotes an argument about the use of the word Rohingya as an ethnic name before 1784 but this claim is highly contested (Ware and Laoutides 2018, pp. 90-92). Their opponents are at pains to demonstrate that the term Rohingya appeared in the 1950s during the post-independence period. The direct outcome of such a claim is the starting point of the counter-narrative which is encapsulated in the thesis that the Rohingya are not autochthonous but rather a disparate group of immigrants, at best. Accordingly, Arakanese and Burmese Buddhists see the popularisation of the name as part of a dangerous political agenda intent on claiming self-rule over territory, and thus an imminent threat of assault on the sovereignty and territorial integrity of the country.

The insistence on the use of Rohingya as a historical term to describe the pre-colonial Muslim population in Rakhine is perceived by the Arakanese and Burmese Buddhists as instrumental in including under the term the Muslim immigrants from British India during the colonial era (Leider 2015, 2017). These populations migrated and settled in Rakhine state and became the majority of the Muslim population in the state's northern part. This melting of diverse communities with the parallel use of the term Rohingya to claim distinct ancestral presence was received with concern and suspicion. Suspicion became gradually fear under a narrative of infiltration and siege. The central tenet of this narrative is that the Rohingya are Bengalis who arrived in Myanmar under British rule, during the Pakistan-Bangladesh civil war as refugees and many as illegal immigrants from Bangladesh. Building on the assumption of a Muslim influx in the country, Buddhist religious leaders claim that Muslims are infiltrating the country. The very controversial Buddhist monk U Wirathu has repeatedly referred to a Muslim conspiracy to take over Burma through economic activity and interfaith marriage (Galache 2013). In this line U Wirathu describes the problem as " ... one of religious colonization ... What they [the Muslims] aim is to make the whole world Islam" (Holt 2019, p. 213). This view is shared by many Arakanese; in 2017 a commonly articulated public perspective by an Arakanese was that:

"There is a well-planned strategy by Bangladesh Muslim terrorists together with other power Islamic countries to in one way or another destabilize Myanmar. Rakhine people do not like illegal immigrants' bad behaviour and terrorism. They do not want them to stay in Rakhine state because they are trying to riot and destroy a peaceful environment by using well-planned strategies. Rakhine people have a kind heart to allow them to stay 
in the past ... Now Bengalis want to drive away Rakhine people... Openly we say that they are stealing not just our land; they are stealing our fatherland, our forests, and all of our other resources. They are also stealing our honor, dignity and sense of being one Rakhine state. And their aim is to destroy our nation and religion with [an] unlimited birth rate, after that they will try to form an Islamic state in our own land".

(Holt 2019, p. 23)

Interfaith marriage has been singled out as a method for the Muslim infiltration to advance. Walton and Hayward (2014, p. 18) quote an excerpt from one of U Wirathu's (2013) sermons: "[Muslims] have a lot of money and no one knows where that money mountain is. They use that money to get our young Buddhist women. They show that money to attract our young women... That money will be used to get a Buddhist-Burmese woman, and she will very soon be coerced or even forced to convert to Islam ... And the children born of her will become Bengali Muslims and the ultimate danger to our Buddhist nation, as they will eventually destroy our race and our religion. Once they become overly populous, they will overwhelm us and take over our country and make it an evil Islamic nation". An interesting point made by Holt (2019, p. 19) is the reference to rape as the starting point of the recent cycle of violence in 2012 in Rakhine. Violence began when a Buddhist woman was raped by 'Bengali Muslims'. The rape of Buddhist women has also been cited in another two incidents of communal violence in Meiktala and Mandalay. The rape theme, whether real or fake, functions as a metaphor for Muslim penetration in the society but also as an assertion that the Buddhists respond from a position of moral high ground against the barbarous and brutal other.

In turn, Arakanese histories argue that it is the Arakanese people, who are the real victims, robbed of their ancestral homeland, property, and livelihoods by endless Bengali migration. They have been systematically stripped of their rights, property, and identity by the incoming human tide since the colonial period-and particularly via the 1942 massacres (Thawnghmung 2016). There is a real sense of existential threat, that they are being progressively displaced from their homeland by a burgeoning Bengali presence. Rakhine state is often referred to as the country's 'Western Gate', the front line in a battle to protect Myanmar from an invasion described as both external, via migration, and internal, via rapid birth rate, interfaith marriage, and forced conversions (Schissler et al. 2015). For U Wirathu and other MaBaTha senior leaders the response to the "Muslim onslaught" should be fourfold: avoid interethnic and interfaith marriages, instill to children a strong love of nation and religion which will allow them to discriminate against Muslisms, pause any economic transaction with Muslims, and finally vote for nationalist Buddhists only at all levels of government (Foxeus 2019).

As discussed above, the emerging anarchy of periods of transition within countries can amplify the risk of a security dilemma between conflicting ethnoreligious groups. In Myanmar, the democratic transition since the enactment of the 2008 Constitution has created a high degree of uncertainty among ethnic communities of the country. This includes fears about the power of the military, the authority of local officials and how chronic and emerging issues will be addressed. The transitional environment has also allowed social media inter-ethnic enmity to flourish, and rumours to abound. In such a situation, particularly when groups have already become highly fearful of one another as well as of core institutions such as the government and the military, uncertainty about each other's intentions can lead groups to judge each other through the lens of history (Yilmaz and Morieson 2021a). This usually draws on the worst examples of past interethnic relations - in this case, the worst of the historical narratives widely circulated refers to the horrific massacres and widespread acts of ethnic cleansing perpetrated by both local Buddhists and Muslims during the Second World War. It is the unresolved grievances from this period, and lack of any transitional justice, which have in many ways sustained conflict tensions for more than seven decades. Communities that are socially segregated and relatively isolated from their elite are particularly vulnerable to such rumour, fear and overreaction, and to taking measures to protect themselves. 
The intractability of this conflict is grounded on versions of history and increased collective fear fuelled by the sense of existential threat based on cycles of violence. Collective fear feeds further the populist narratives of the 'Other' based on ambivalent evidence, which is very real in its consequence. The fact that both sides so heavily rely on portrayals of history to communicate their fears, grievances and claims, means that history cannot easily be ignored. The fact that local actors use historical narratives to bolster the sense of the rightness of their own cause and the unjust and immoral nature of the others makes engagement with the history an essential component of any meaningful intervention. Truth and exaggeration are present in the narratives of all sides, typically underpinned by unfounded assumptions and myths. Certainly, uncritical acceptance of the historical narrative of one side cannot pave the way for any reconciliation.

\section{Towards a Politics of Balancing Fear}

The ethnoreligious conflict in Rakhine state is characterised by collective fear, which facilitates the shaping and maintaining of collective identity but also affirms the emotive intersection between religion and populism as a means to create and maintain dichotomies of otherness (Yilmaz and Morieson 2021b). Shared perceptions of common past experience and expectations increase the interconnectedness of the individuals within the ethnic group (Ross 2007). These connections strengthen the social categories that determine group and individual behaviour. Social action and innovation take place within the framework of culture, the system of beliefs and meaning that individuals and groups use to interpret reality. If minorities are significantly different, they are less likely to assimilate, and thus they can become targets for the externalization of the most powerful group's fears and self-images, attracting suspicion and antipathy because of their 'different' characteristics (Volkan 1988). The emotional significance apportioned by individuals to collective membership is a constitutive element of social identities which are relational (Tajfel 1981, p. 63). Given that social identities are predicated on differentiation as much as inclusion, in many ways "we are what we are not" (Demmers 2017, p. 23; emphasis in the original). Rohingya, Arakanese, and Burmese group narratives give an account of their origin, history, and conflicts with the other sides. Ethnic fear becomes more intense when narratives depict past deep trauma in the inter-ethnic relations, such as the massacres during the Second World War, episodes of ethnic dominance and so on.

Following the enunciation of ethnicity as the sole criterion for membership in the polity of Myanmar historical memory has been re-imagined by ethnic entrepreneurs for various purposes. Questions of identity and ethnicity have been prominent in the existential threat felt by each group. Although the type of threat may vary, it is perceived as real in all cases, with serious consequences. For the Rohingya, the existential fear stems from the violence they have experienced over the past seventy-five years, at the hands of either the Arakanese (1942 and 2012) or the Burmese military (1978, 1991-1992, 2016-2017). Their collective memory of persecution is further enhanced by a narrative of indirect or structural violence, constituted by collective discrimination in the form of restrictions on movement, denial of citizenship, forced segregation, and internal displacement. These traumatic experiences have influenced the language of fear and threat employed by the Rohingya. It results in a siege mentality, the self-image of a homeless and helpless population suffering ongoing gross injustice (Anderson 2006). This has forged a sense of shared Rohingya identity out of what was originally an ethnically diverse community of Muslims in Arakan (pre-colonial and colonial times). The emergence of a common identity has been constituted dialectically, in contrast to 'the Other', the common oppressor. The demonization of the Rohignya based on a process of alienation from the national body politic, via ethnicity, can thus offer some insights into violence and conflict in Rakhine, as can the systemic pressure to subjugate or assimilate the Arakanese. Identity politics and the building of a negative image of the Other as a means of enhancing in-group cohesion, elevation, and survival, can explain the narratives of fear leading to episodes of violence. 
In addition, the analysis of existential fear narratives in the ethnic conflict in Rakhine state echoes the comment by Robin $(2004$, p. 20) that fear is not confined to the powerless. The prospect of losing power will typically lead the powerful group to a climate of fear begging for collective action to prevent the perceived threat of power loss. As an intersubjective experience, collective fear is aroused when groups are able to impute the perceived danger onto an enemy (TenHuten 2007, p. 43). This is illustrated in the analysis above by the narrative of Muslim infiltration in Myanmar and the subsequent collective fear (real to the group) of the country turning into an Islamic state. The conventional options of collective behaviour are summarised by Kemper (1978) based on a causal account of fear. For Kemper, the structural conditions of insufficient capabilities or the perceived increased power of the other side, gives rise to fear (Kemper 1978, pp. 55-58). Accordingly, it is possible to determine whether fight or flight behaviour will occur based on an assignment of responsibility for the group's power deficit. If the group's assessment of the sources of their powerlessness indicate incapacities within the group, then flight is the most likely fear behaviour (subjugation). Alternatively, if the other side is the agent of the group's insufficient power, then the group's behaviour will incline towards fight (rebellion). However, the conventional categories of flight and fight, or subjugation and rebellion, are inadequate to account for the fearful action of the Buddhist elites (mainly Bama-dominated elites in the government and the military as well as the Arakanese political leaders) who are able to deploy resources for the containment of negative prospects perceived as constituting an existential fear. Similarly, flight or fight does not account for the lack of large-scale violent mobilization of the Rohingya after seventy years of discrimination and several episodes of collective violence against them. However, if subjugation or rebellion cannot explain collective fear in an emerging anarchy then what is the path forward to address the realm of threat and fear in ethnic conflicts?

A possible response to the dilemma fight or flight acknowledges a more nuanced story of fear that departs from hate and killing. Halperin (2008), reflecting on his long-term engagement with the Palestinian-Israeli conflict, observes that people who feel fear want to secure their own as well as their collective present and future rather than cause harm to the out-group. Although guaranteeing the future can involve aggression and violence, societies dominated by fear may see favourably any solution, such as compromise, that can potentially reduce the prospect of injury and harm and thus reduce fear (Halperin et al. 2013). In my view, such an observation could be also informed by the idea of emotions as the residue of lived experience which can change long term beliefs and attitudes (Petersen 2017). According to Petersen, the transformative power of emotions relies on the ability of emotions to affect the belief formation between ethnic groups and to harden their long-term attitudes (Petersen 2017, p. 933). The main challenge of those trying to promote resolution and reconciliation is to create the conditions whereby a compromise approach is framed as a 'threat-reduction' process which can penetrate the filters of belief formation and attitudes (Halperin 2016). If the same experience triggers fear in everyday interactions in a group, then fear can have long-term collective effects. Thus, the 'threat-reduction' process should intend not to decrease fear but rather to channel it towards more constructive tendencies (Halperin 2014).

Furthermore, from a sociological point of view, Barbalet and Demertzis (2013) share the need for a constructive turn in collective fear behaviour and move away from the dichotomy of subjugation or rebellion. Accordingly, they argue that containment is the process of "putting in place what was previously absent" (Barbalet and Demertzis 2013, p. 178). A power deficit may be addressed by the structural channelling of power between the groups so as to create a 'threat-reduction' opportunity in order to reposition the groups and reduce the power asymmetry. Drawing on the above, it seems that in the context of ethnic conflicts containment should take into account three different dimensions of fear. First, the central role that ethnic identity plays in the politics of fear through the reiteration of narratives of otherness. Second, the structural conditions of emerging anarchy that are generated by historico-political transitions and the readjustment of these conditions 
(effective governance, economic development, security guarantees) towards a 'threatreduction' environment. Third, the allocation of the necessary resources for containment to eventuate; as Barbalet and Demertzis (2013, p. 178) suggest, the resources required for containment are much higher than those necessary for subjugation and rebellion.

In the case of Rakhine, ethnic conflict is the product of otherness, fear and hate. The use of ethnicity as the criterion of political membership in Myanmar created dividing lines which informed further the distinction between us and them, friends and enemies, civilized and barbarians. Although it is crucial to think of containment as a process of 'threat-reduction', it must not distract us from the fact that the institutional structures of the Myanmar state have created and reproduced those notions of otherness. Thus, an attempt to constructively channel fear should not be only looking to do away with the need of a collective other; rather the challenge in the politics of balance (in ethnic conflict) is the move away from institutional notions of exclusion (i.e., ethnicity) that create and maintain imagined enemies.

Funding: This research received no external funding.

Institutional Review Board Statement: Not applicable.

Informed Consent Statement: Not applicable.

Data Availability Statement: Not applicable.

Conflicts of Interest: The author declares no conflict of interest.

\section{Note}

1 This article does not discuss the immediate findings of fieldwork data in Rakhine state. It rather reflects on personal observations (whilst working in the field) along with the use of secondary sources.

\section{References}

Anderson, Benedict. 2006. Imagined Communities: Reflections on the Origin and Spread of Nationalism, Revised ed. London: Verso.

Barbalet, Jack, and Nicolas Demertzis. 2013. Collective fear and societal change. In Emotions in Politics: The Affect Dimension in Political Tension. Edited by Nicolas Demertzis. Basingstoke: Palgrave Macmillan, pp. 167-85.

Bar-Tal, Daniel. 2013. Intractable Conflicts: Socio-Psychological Foundations and Dynamics. Cambridge: Cambridge University Press.

Bar-Tal, Daniel, and Eran Halperin. 2013. The psychology of intractable conflicts: Eruption, escalation and peacemaking. In Oxford Handbook of Political Psychology. Edited by Leonie Huddy, David O. Sears and Jack S. Levy. New York: Oxford University Press, pp. 923-56.

Bar-Tal, Daniel, Lily Chernyak-Hai, Noa Schori, and Ayelet Gundar. 2009. A sense of self-perceived collective victimhood in intractable conflicts. International Red Cross Review 91: 229-77. [CrossRef]

Bauman, Zygmunt. 1991. Modernity and Ambivalence. Cambridge: Polity Press.

Ben-Ze'ev, Aaron. 2000. The Subtlety of Emotions. Cambridge: The MIT Press.

Castoriadis, Cornelius. 1987. The Imaginary Institution of Society. Cambridge: The MIT Press.

Cheesman, Nick. 2017. How in Myanmar "national races" came to surpass citizenship and exclude the Rohingya. Journal of Contemporary Asia 47: 461-83. [CrossRef]

Coli, Daniela. 2006. Hobbes's revolution. In Politics and the Passions, 1500-1850. Edited by Victoria Kahn, Neil Saccamano and Daniela Coli. Princeton: Princeton University Press, pp. 75-92.

Darwin, Charles. 1965. The Expression of the Emotions in Man and Animals. Chicago: University of Chicago Press.

de Figueiredo, Rui J. P., and Barry R. Weingast. 1999. The Rationality of Fear: Political Opportunism and Ethnic Conflict. In Civil Wars, Insecurity and Intervention. Edited by Barbara Walter and Jack Snyder. New York: Columbia University Press, pp. $261-302$.

Demmers, Jolle. 2017. Theories of Violent Conflict: An Introduction. London: Routledge.

Elman, Miriam F., Catherine Gerard, Galia Golan, and Louis Kriesberg, eds. 2019. Overcoming Intractable Conflicts: New Approaches to Constructive Transformations. Lanham: Rowman \& Littlefield.

Fearon, James D. 1998. Commitment Problems and the Spread of Ethnic Conflict. In The International Spread of Ethnic Conflict. Edited by David A. Lake and Donald Rothchild. Princeton: Princeton University Press, pp. 107-26.

Foucault, Michel. 2003. Society Must Be Defended. New York: Picador.

Foxeus, Niklas. 2019. The Buddha was a devoted nationalist: Buddhist nationalism, ressentiment, and defending Buddhism in Myanmar. Religion 49: 661-90. [CrossRef]

Galache, Carlos S. 2013. Who Are the Monks behind Burma's '969' Campaign? Available online: http:/ /www.dvb.no/news/featuresnews / the-monks-behind-burma\%E2\%80\%99s-\%E2\%80\%9C969\%E2\%80\%9Dmovement-2/28079 (accessed on 12 June 2021). 
Halperin, Eran. 2008. Group-based hatred in intractable conflict in Israel. Journal of Conflict Resolution 52: 713-36. [CrossRef]

Halperin, Eran. 2014. Collective emotions and emotion regulation in intractable conflicts. In Collective Emotions. Edited by Christian von Scheve and Mikko Salmela. Oxford: Oxford University Press, pp. 282-96.

Halperin, Eran. 2016. Emotions in Conflict: Inhibitors and Facilitators of Peace Making. London: Routledge.

Halperin, Eran, Roni Porat, and Michael Wohl. 2013. Extinction threat and reciprocal threat reduction: Collective angst predicts willingness to compromise in intractable intergroup conflicts. Group Processes and Intergroup Relations 16: 797-813. [CrossRef]

Heaney, Jonathan. 2013. Emotions and nationalism: A reappraisal. In Emotions in Politics: The Affect Dimension in Political Tension. Edited by Nicolas Demertzis. Basingstoke: Palgrave Macmillan, pp. 243-63.

Helm, Bennett W. 2001. Emotional Reason: Deliberation, Motivation, and the Nature of Value. Cambridge: Cambridge University Press.

Hobbes, Thomas. 2004. Leviathan. New York: Barnes \& Noble.

Holt, John C. 2019. Myanmar's Buddhist-Muslim Crisis: Rohingya, Arakanese, and Burmese Narratives of Siege and Fear. Honolulu: University of Hawai'i Press.

Horowitz, Donald. 1985. Ethnic Groups in Conflict. Berkeley: University of California Press.

Horowitz, Donald. 2001. The Deadly Ethnic Riot. Berkeley: University of California Press.

Jervis, Robert. 1978. Cooperation under the Security Dilemma. World Politics 40: 167-214. [CrossRef]

Kahneman, Daniel. 2011. Thinking Fast and Slow. London: Penguin.

Kaufman, Stuart J. 2001. Modern Hatreds: The Symbolic Politics of Ethnic War. Ithaca: Cornell University Press.

Kemper, Theodore D. 1978. A Social Interactional Theory of Emotions. New York: Wiley.

Lake, David A., and Donald Rothchild. 1996. Containing fear: The origins and management of ethnic conflict. International Security 21: 41-75. [CrossRef]

Lake, David A., and Donald Rothchild. 1998. Spreading fear: The genesis of transnational ethnic conflict. In The International Spread of Ethnic Conflict: Fear, Diffusion, and Escalation. Edited by David A. Lake and Donald Rothchild. Princeton: Princeton University Press, pp. 3-32.

Lake, David A., and Donald Rothchild. 2001. Political Decentralization and Civil War Settlements. Paper presented at the Annual Meeting of the American Political Science Association, San Francisco, CA, USA, August 30-September 2.

Leider, Jacques P. 2013. Rohingya: The name, the movement, the quest for identity. In Nation building in Myanmar. Yangon: Myanmar Peace Centre, pp. 204-55.

Leider, Jacques. 2015. Competing Identities and the Hybridized History of the Rohingyas. In Metamorphosis: Studies in Social and Political Change in Myanmar. Edited by Renaud Egreteau and Francoise Robinne. Singapore: National University Singapore Press, pp. 151-78.

Leider, Jacques. 2017. Transmutations of the Rohingya Movement in the Post-2012 Rakhine State Crisis. In Ethnic and Religious Identities and Integration in Southeast Asia. Edited by Ooi K. Gin and Volker Grabowsky. Paris: École Française d'Extrême-Orient (EFEO), Chiang Mai: Silkworm, pp. 191-239.

Lerner, Jennifer S., and Dacher Keltner. 2001. Fear, anger and risk. Journal of Personality and Social Psychology 81: 146-59. [CrossRef] [PubMed]

Malesevic, Sinisa. 2004. The Sociology of Ethnicity. London: Sage Publications.

Médecins Sans Frontières. 2017. Myanmar/Bangladesh: MSF Surveys Estimate that at least 6700 Rohingya were Killed during the Attacks in Myanmar. December 12. Available online: https://www.doctorswithoutborders.org/what-we-do/news-stories/ research/msf-least-6700-rohingya-killed-during-attacks-myanmar (accessed on 14 June 2021).

Mozur, Paul. 2018. A Genocide Incited on Facebook, With Posts from Myanmar's Military. New York Times, October 15.

Oatley, Keith, and Jennifer Jenkins. 1996. Understanding Emotions. Oxford: Blackwell Publishing.

Ortony, Andrew, Gerald L. Clore, and Allan Collins. 1988. The Cognitive Structure of Emotions. Cambridge: Cambridge University Press.

Petersen, Roger D. 2002. Understanding Ethnic Violence: Fear, Hatred, and Resentment in Twentieth-Century Eastern Europe. Cambridge: Cambridge University Press.

Petersen, Roger D. 2017. Emotions as the Residue of Lived Experience. Political Science and Politics 50: 932-35. [CrossRef]

Posen, Barry R. 1993. The Security Dilemma and Ethnic Conflict. Survival 35: 27-47. [CrossRef]

Robin, Corey. 2004. Fear: The History of a Political Idea. Oxford: Oxford University Press.

Roe, Paul. 2005. Ethnic Violence and the Societal Security Dilemma. Abingdon: Routledge.

Roseman, Ira J. 1984. Cognitive determinants of emotions: A structural theory. Review of Personality and Social Psychology 5: 11-36.

Ross, Marc Howard. 2007. Cultural Contestation in Ethnic Conflict. Cambridge: Cambridge University Press.

Said, Edward. 1991. Orientalism. London: Penguin.

Schissler, Matt, Matthew J. Walton, and Phyu Phyu Thi. 2015. The Roots of Religious Conflict in Myanmar. The Diplomat, August 6.

Schmid, Hans B. 2009. Shared feelings: Towards a phenomenology of collective affective intentionality. In Plural Action: Essays in Philosophy and Social Science. Edited by Hans B. Schmid. Berlin: Springer, pp. 59-83.

Smith, Adam. 1982. The Theory of Moral Sentiments. Indianapolis: Liberty Classics.

South, Ashley. 2008. Ethnic Politics in Burma: States of Conflict. London: Routledge.

Stephan, Walter G., C. Renfro, and M.D. Davis. 2008. The role of threat in intergroup relations. In Improving Intergroup Relations. Edited by Urlich Wagner, Linda R. Tropp, Gillian Finchilescu and Colin Tredoux. Oxford: Blackwell, pp. 55-72.

Tajfel, Henri. 1981. Human Groups and Social Categories. Cambridge: Cambridge University Press. 
Taylor, Kathleen Eleanor. 2009. Cruelty: Human Evil and the Human Brain. Oxford: Oxford University Press.

TenHuten, Warren. 2007. A General Theory of Emotions and Social Life. London: Routledge.

Thawnghmung, Ardeth Maung. 2016. The Politics of Indigeneity in Myanmar: Competing Narratives in Rakhine State. Asian Ethnicity 17: 527-47. [CrossRef]

U Wirathu. 2013. Public Sermon Posted on Hla Oo's Blog. Available online: http://hlaoo1980.blogspot.com/2013/03/boycott-muslimbusinesses-nationalist.html (accessed on 12 July 2021).

Van Evera, Stephen. 1994. Hypotheses on Nationalism and War. International Security 18: 5-39. [CrossRef]

Volkan, Vamik. 1988. The Need to have Enemies and Allies: From Clinical Practice to International Relationships. Northvale: Aronson.

Walton, Matthew J., and Susan Hayward. 2014. Contesting Buddhist Narratives: Democratization, Nationalism, and Communal Violence in Myanmar. Policy Studies 71, East-West Centre Policy Series; Honolulu: East-West Center.

Waltz, Kenneth. 1979. Theory of International Politics. New York: McGraw Hill.

Ware, Anthony, and Costas Laoutides. 2018. Myanmar's 'Rohignya' Conflict. London: Hurst.

Yilmaz, Ihsan, and Nicholas Morieson. 2021a. A Systematic Literature Review of Populism, Religion and Emotions. Religions 12: 272. [CrossRef]

Yilmaz, Ihsan, and Nicholas Morieson. 2021b. Different Ways in Which Religion and Populism Intersect within World's Great Faiths. European Centre for Populism Studies, May 8. Available online: https://www.populismstudies.org/different-ways-in-whichreligion-and-populism-intersect-within-worlds-great-faiths / (accessed on 10 September 2021). 